\title{
A Secular Age and Islamic Modernism
}

\section{Introduction}

Why use A Secular Age for research on modern Islamic self-understandings? ${ }^{1}$ After all, Taylor explicitly limits his story to what he imagines to be the West. The problems with this imagination as well as with the conceptual pairing of 'Islam' and the 'West' have been stressed in the introduction to this volume and need not be repeated. ${ }^{2}$ What is important here is that modernity, even though it only evolved in the encounter among different regions, came to be epitomized by the West; that is, the understanding of modernity (self-)ascribed to the West became hegemonic for, or even conflated with, the understanding of modernity at large. Studies pointing to the power mechanisms at work in the construction and perpetuation of this Western hegemony are of course important. However, whether we deplore the fact or not, we cannot write power out of history.

Critiquing the hegemony of an imagined West as reflected in A Secular Age thus does not solve another, larger problem resulting from this hegemony: research on Islamic contexts is continuously forced to resort to Western theories and self-understandings, for there are no equally powerful Islamic versions of modernity or secularity. Simply assuming the validity of Western accounts beyond their original context is obviously not an option. Yet, the potential alternative, of inductively establishing Islamic (hi)stories of modernity via historical and empirical research, has a long way to go - due largely to a sheer lack of workforce and the vastness of the empirical field. A temporary solution to this dilemma is to use Western theory, history, or, in our case, self-understandings as a heuristic tool to shed light on Islamic contexts. It is in this sense that A Secular Age can fruitfully be applied to Islamic self-understandings.

For their remarks on various versions of this chapter, I would like to thank Colin Jager, Junaid Quadri, Frank Peter, Reinhard Schulze, and Johannes Stephan. Ariel Pate very much improved the English of this text.

1 Previous works using A Secular Age for research on Islamic and other non-Western contexts are Appleby (2011) and Madsen (2011). See soon: Bilgrami (forthcoming); Künkler, Madeley, and Shankar (forthcoming).

2 See pages 14-15. 
In the second section of this chapter I elaborate why and in what sense I take A Secular Age to be a promising tool for research on modern Islamic self-understandings, and why I consider Taylor's story advantageous over other accounts. Briefly, it is because Taylor grasps the most profound background understandings of modernity - that is, background understandings common not only to believers and non-believers in the West but possibly also to non-Westerners. After all, as section three of this chapter suggests, Islam may be absent from A Secular Age, but it is very much present in our common secular age. If we agree that the endpoint of Taylor's narrative is sufficiently shared, then an understanding of developments in Islamic (hi)stories via Taylor's story becomes plausible. The general considerations of sections two and three also prepare the ground for the following case studies by Junaid Quadri and Johannes Stephan.

My own case study offers some first observations on the concept of 'society' in Islamic modernism. As I argue in section four, the broader relevance of these observations lies in the concept of 'society' reflecting the meta-norm of Taylor's modern social imaginaries, which underlie our self-understanding as living in a secular age. The Arabic term most pertinent for expressing the modern meaning of 'society' is mujtama'. Section five analyzes the usage of mujtama' in the journal al-Manar (Cairo, 1898-1940), widely considered to be the mouthpiece of Islamic modernism. I show that, contrary to previous assumptions, 'society' was already the dominant meaning of mujtama' in the first issue of al-Manar. Moreover, familiarity with European thought greatly facilitated the usage of mujtama in this meaning. In turn, the authors writing regularly for al-Manar and especially the journal's editor, Rashid Rida advanced terms from within the Islamic discursive tradition as alternatives to mujtama', most conspicuously umma.

In the epilogue I suggest that the asymmetric power constellations of colonialism, with the West's claim of exclusivity for its version and genealogy of modernity, have generally made it harder for Muslim intellectuals to bring forward their own stories. This is why the authors of al-Manar, while understanding themselves historically, resorted to expressing distinctly modern understandings via the allegedly timeless essence of Islam.

\section{A Secular Age as a heuristic tool}

Two peculiarities of working with $A$ Secular Age in general also apply to research on modern Islamic self-understandings: Firstly, A Secular Age, being the impressively rich and complex work that it is, can only be approached selectively. Working with instead of working on A Secular Age simply cannot do justice to all the complexities of Taylor's story. Thus the interdisciplinary task is not about getting 
Taylor right (in all his details); it is rather about using A Secular Age to get one's primary object of study 'right,' that is, to grasp it more adequately and portray it more comprehensibly. Such an approach might sound unsatisfactory to participants in theoretical debates, who strive for consistency and systematization. However, because research on Islamic contexts must generally resort to theories elaborated in and for a Western context, sticking to these theoretical models wholeheartedly runs the danger of distorting one's own object of research. For this reason I advocate a pragmatic and selective usage of such theories as means, not ends unto themselves. Of course, not distorting the theory out of its original shape is desirable in order to facilitate conversation with other usages of this theory and possibly contribute to circumscribing the potentials and limits of the theory itself. Secondly, one also needs to address the fact that $A$ Secular Age is not a theory in the conventional sense; it is a story containing both a descriptive and a normative level.

A major advantage of $A$ Secular Age over most accounts of secularization and theories of secularity lies in Taylor's magisterial deconstruction of the oft-presumed binary between religion and secularism and between religious and secular stances. ${ }^{3}$ Taylor convincingly shows what religious and secular modern Westerners fundamentally share: the idea of an immanent frame, which some - those believing in God - read as open and others - those believing that the immanent frame is all there is - as closed (ASA: 543-544; Taylor 2010a: 306 -307). In this vein Scott Appleby (2011) has depicted Islamic fundamentalists as upholding an "open spin” of the immanent frame. Considering that the modern character of fundamentalists is often exclusively illustrated by their use of technology and media, this application of Taylor's concept offers a more foundational reading. A similarly powerful concept, which also shows the commonalities between seemingly adversarial positions, is the "fullness" to which all humans aspire (ASA: 5-12).

Both concepts, "the immanent frame" and "fullness," have been extensively criticized for their underlying Christian bias (Gordon 2008; Schweiker 2009; Connolly 2010; Sheehan 2010). Indeed, in the end Taylor does conceive of the immanent frame so that its "closed spin" appears as deficient, and fullness can only be truly achieved when it involves striving for something beyond this world. So Taylor is not speaking from nowhere - but who is? Taylor rightfully points to academia as the milieu where unbelief most clearly became the hegemonic option,

3 I am using 'secularization' for the process of making or becoming secular, 'secularity' as the description of the outcome of this process, and 'secularism' for normative positions advocating secularization. 
with most academics reading the immanent frame as closed. This reading is even more dominant when it comes to theory-making, where personal beliefs are expected to be put aside: if one wants to presume an open reading, one has to do theology.

The secular bias of most academic disciplines has been acknowledged by secular theorists themselves, who saw it leading to blindness to religious phenomena, and therefore to a misconception of reality. However, these theorists, of whom Jürgen Habermas is a prominent example, trying to find more adequate theoretical models is not accompanied by abandoning their own personal stances, which still are discernable from their remodeled theoretical conceptions. ${ }^{4}$ From the side of believing academics, meanwhile, reality certainly will not be portrayed more adequately by trying to subsume all secular knowledge production under a theological framework. ${ }^{5}$ Here Taylor's book offers a far more constructive, integrated account that actually complements secular theories. Rejecting a religiously-informed conception, like Taylor's, due to its underlying bias - a charge that can, of course, go both ways - would prematurely inhibit this complementary potential. Secular research on religious topics in particular can benefit from resorting to Taylor's ideas, as they make the phenomena at hand more intelligible. In short, Taylor's depiction of modernity and secularity allows for the integration of religious phenomena - including Islamic ones - into a common framework of understanding.

Logically, there are four possible explanations for commonalities between Western and Islamic contexts: a) similar understandings ${ }^{6}$ which have evolved autonomously in both contexts and then converged; b) an understanding evolved in mutual contact and exchange; c) hegemony of the Western understanding in an Islamic context; and d) vice versa. In reality, these explanations are not always clearly separable. At least since colonial times we would primarily expect a mixture of b) and c). For example, the idea of an 'us' living in an immanent frame evolved in distinction from a supposed Islamic other; yet, once this idea had became hegemonic, Muslim thinkers, too, had to at least refer to the immanent frame, even if in negation of it respectively of its closed spin. Thus, the immanent frame might not only be common to believers and unbelievers in the West, as Taylor has it, but also to Westerners and non-Westerners.

4 See the debate between Habermas and Taylor (2011).

5 See Milbank (1991) for a prominent example.

6 These possibilities would also hold true for historical phenomena; I use 'understanding' here because A Secular Age, and especially my usage of it here, is concerned less with empirical reality than with self-understandings. 
Having shown the desirability of using A Secular Age as a heuristic tool for research on Islamic contexts, it remains to establish the plausibility of doing so. The less the secular age is confined to the West, the more similarities between Western self-understandings as depicted in Taylor's story and Islamic self-understandings we may suspect. And, indeed, I will now argue that while Islam is absent from the genealogy of secularity Taylor narrates, it is present in our common secular age.

\section{Islam as absent from $A$ Secular Age but present in the secular age}

"Above all, I have neglected the way in which Western understandings of religion were informed through the pre-colonial and then the colonial encounter with other parts of the world [...]" (Taylor 2010a: 301). With this statement, Taylor early on in the debate on A Secular Age acknowledged a central criticism directed at the book, namely that the story of Latin Christian secularization can't be told without taking into account the contributions of Latin Christendom's others, both within and beyond the North Atlantic world. This point has been most forcefully argued by Saba Mahmood (2010). Mahmood advances another point of criticism, namely that the civilization Taylor limits his story to, which he alternately designates as "North Atlantic world," "Latin Christendom," or "the West," is not a given but itself a historical construction. This is why, "[t]he boundary Taylor draws around Latin Christendom is difficult, if not impossible, to sustain for both historical and conceptual reasons" (Mahmood 2010: 296). Taylor indeed rather uncritically adopts discursive categories that evolved from and strengthen Western hegemony; however, to be fair, he did not invent 'the West,' nor its hegemony, himself.

What is more, Taylor's intention in drawing a boundary around Latin Christendom is less to exclude others but rather to isolate this previously constructed civilization with the aim of better understanding it. Taylor advocates the idea of multiple modernities, according to which crucial features of modernity, most profoundly secularity, are constituted and expressed differently in different "civilizations" (ASA: 21; Taylor 2011a). He defends his decision to limit A Secular Age to the West as wanting to avoid premature universalization; only after an indepth study of one civilization could one attempt comparisons with other contexts (ASA: 21; Taylor 2011a: 36-37). Taylor is quite consistent in his self-imposed limitation: there are only few allusions to the non-West on the pages of $A$ Secular Age, most remarkably parallels between Christianity and Buddhism. The few 
times Islam is mentioned in Taylor's story, it is both as a counter-example (ASA: 102, 283, 419) and to illustrate commonalities (ASA: 154, 608, 781fn19). Unlike many contemporary debates on secularity, the central counter-foil to our contemporary Western societies in A Secular Age is not Islam but the West's own past, ${ }^{7}$ and Taylor explicitly criticizes the othering of Islam for the sake of assuring one's own secularity (ASA: 770, 834fn19).

Then again, Taylor's interest in an understanding of a secularity allegedly specific to the West goes along with an exclusion of the non-West, including Islam. At the beginning of $A$ Secular Age, Taylor names two common characterizations of secularity, secularity 1 , the "emptying" of public spaces of God, or what more commonly would be termed social differentiation; and secularity 2 , "the falling off of religious belief and practice" (ASA: 1-2). According to the latter understanding, the United States, Pakistan, and Jordan - exemplary cases for the West and the non-West - would be classed "as the same" (ASA:3), and this is not the secularity of his interest. Taylor is interested in an understanding of secularity that brings out the specifics of Western societies, with Muslim societies serving as contrast cases. To him, the West's specific secularity (secularity 3) consists of the asserted fact that belief in God is no longer axiomatic but has become a mere option. If these supposedly specific characteristics then serve as the benchmark for whether "an age or society" is "secular or not" (ASA: 3), the answer is a given - only "we'8 are secular. Therefore, while Taylor names characteristics of secularity extending to the non-West, he advances an understanding that turns 'secularity' into a placeholder for 'our' alleged exclusivity.

However, while less obvious than regarding secularity 1 and 2, Taylor's own characterization is not all that exclusive to the West, either. One can hardly doubt the predominance of "secularity 1" throughout the Islamic world. Gudrun Krämer, in an article that also draws on Taylor, leaves no doubt that this is a historical fact: "A close look at modern political thought and practice (including notably Islamic discourse), economics, law, art and education would reveal that secularization processes form an integral part of Middle Eastern history and society" (Krämer 2013: 630). As Krämer notes, the question is rather how Muslims position themselves towards this factual secularity. Regarding secularity 2, the decline of religious beliefs and practices, Taylor himself has stated that the United States (as a crucial example of the West) is on the same level as Islamic countries Jordan and Pakistan (ASA: 3). The issue is indeed less clear regarding secularity

7 That is why Taylor cannot acknowledge historians' empirical claims that complicate his picture of past societies as holistically and harmoniously grounded in transcendence (Gordon 2008; Sheehan 2010).

8 For a complication of Taylor's “we," see Tester (2010). 
3, the optionality of belief. Taylor of course has not settled on this understanding without reason, pointing out Muslim societies as clear counter cases. Yet even in Islamic societies, belief is no longer axiomatic; these societies might instead appear as counter cases because belief is the hegemonic option.

Let us approach this argument from its least controversial side: Nilüfer Göle has indisputably shown that migrant Muslims, especially in a European setting, use Islam as a means for individual "self-fashioning” (Göle 2010: 261). ${ }^{9}$ As argued by Krämer (2013: 635), the spread of new media might also multiply the options available in Muslim majority societies. But unbelief as an option has not become available only recently. Samuli Schielke (2012: 302) reminds us that "nonreligion and atheism have long had supporters among Muslim peoples too." These supporters may be few in number, but contemporary Islamic revival movements should not deceive one into thinking that belief is axiomatic. Rather, these very movements testify to belief being an option, and, through failing to deliver on their comprehensive agenda, may even motivate people to embrace unbelief (Schielke 2012: 302). True, in Muslim majority societies, even fewer people are put in that "Jamesian open space" (ASA: 549, 551, 592) than in the West. But at least since the colonial era, a naive, unreflective belief has become unavailable to many milieux in Islamic societies. ${ }^{10}$ Since then, religion as a basis for society has been disputed even more profoundly, with secularism, nationalism, and socialism representing major competitors to religious agendas.

This rough sketch suggests that while Islam is absent from Taylor's story, it does participate in our common secular age as conceived of in A Secular Age. The background understandings which, according to Taylor, made possible and continue to support the secular age, and which are more fundamental than the degree to which belief is an option, can therefore be used as heuristic tools for research on Islamic contexts. Interestingly, Taylor himself tentatively suggests Islam as the one tradition next to Western Christendom that produces a crucial landmark of his story, namely the division between a natural and a supernatural order (ASA: 781fn19). In the following two chapters of this volume, two other landmarks are addressed: Junaid Quadri shows the convergence of the Arabic term din with the modern concept of 'religion,' and Johannes Stephan identifies the idea of civilization and immanent progress in nineteenth century Arabic literature. My own case study offers observations on the concept of 'society' in Islamic modernism. The broader relevance of these observations lies in the con-

9 One could fully attribute this fact to the European environment; however, for cultural accounts stressing the importance of religious traditions, like Taylor's, Muslims within European societies are relevant signifiers of an Islamic self-understanding.

10 This is not only true for urban areas (Loeffler 1988). 
cept of 'society' reflecting of the meta-norm of Taylor's modern social imaginaries.

\section{Modern social imaginaries and the concept of 'society'}

Working with A Secular Age in an Islamic context requires greater caution than in the Western context for which Taylor elaborated his story; still, most of Taylor's concepts and descriptions require testing for the West as well. This concerns fundamental concepts like the distinction between immanence and transcendence as well as empirical descriptions like the contemporary hegemony of secular stances. ${ }^{11}$ It should be clear that such testing is only feasible for individual cases and not for the West or Islam in general. However, as I see it, counter-examples do not make Taylor's story meaningless, for it still speaks to us. ${ }^{12}$ Remember that the landmarks of Taylor's story are not really situated on the level of empirical reality but rather capture a certain self-understanding. Taylor (2010a: 314) describes himself not as a historian but as "a mapper of social imaginaries."

A social imaginary consists of the most profound background understandings of how we make sense of ourselves and of our relations with others. While this background, which is normative insofar as it is regulating social life, cannot be clearly delimited, "one way of defining a social imaginary is as the kind of collective understanding that a group has to have in order to make sense of their practices" (2010a: 315). To Taylor it is different social imaginaries that most profoundly account for cultural differences across regions and ages. Taylor's multiple modernities are in the end due to multiple social imaginaries, with the modern Western imaginary differing from all previous imaginaries and from all non-Western imaginaries. It is the difference in imaginaries which allegedly makes 'us' secular and 'them' not. Discerning the modern Islamic social imaginary might therefore take Taylor's depiction of the West's allegedly specific imaginary (Taylor 2004; ASA: 159-211) as a starting point.

But before getting to the specifically modern social imaginary, I suggest departing from Taylor's general usage of the concept in two points: Firstly, Taylor

11 Taylor (2010b: 411), in response to Hauerwas and Cole (2010), acknowledged that he portrayed immanence and transcendence in too binary a way. For an empirical questioning of Taylor's assessment of the dominance of secularism, see Miller (2008); Abbey (2010).

12 Of course, not every Westerner sees her self-understanding adequately expressed by Taylor. 
distinguishes social imaginaries from theories, for he aims to analyze the unreflectively-held background understandings of whole societies rather than only the reflective theories of elites. Yet surely the latter also hold a certain social imaginary - even when writing theories. This is to say, texts written by elites (and for most of human history, that is all texts) are valid sources for discerning a social imaginary. In the end, Taylor mainly relies on such texts too, positing that the modern social imaginary originated in theory. ${ }^{13}$ Secondly, Taylor, in line with his broad focus on Western civilization at large, tends to speak of the social imaginary held by a society or "the Western social imaginary" (Taylor 2010a: 314). However, as tentatively acknowledged by Taylor himself in the discussions following A Secular Age (Taylor 2010c: 677-678; 2011b: 128), we can hardly expect a uniform imaginary throughout the West - nor, obviously, for all Muslims (but compare Barre 2012). A first attempt at discerning the modern Islamic imaginary should therefore limit itself to a rather specific group of people as the actual carriers of that imaginary (see Strauss 2006) and not claim validity for the Islamic civilization at large.

A promising starting-point for this attempt is a history of concepts: The usage and plausibility of concepts containing a normative dimension, whether explicitly defined or not, is supported by and depends on a social imaginary. As such, concepts provide a fruitful access point to intellectual history. My understanding of a concept follows Ophir's (2011) pragmatic approach, according to which we can turn any word into a concept by problematizing its meaning. Of course, some words as concepts are more fruitful than others. The immense potential of 'society' lies in the fact that it contains the meta-norm of Taylor's modern social imaginaries.

Taylor regards the Christian quest for a civilized order as crucial to the evolution of the modern social imaginary at large - which he illustrates via the three more specific imaginaries of the public sphere, market economy, and democratic self-rule. Beyond what its originators hoped for, the Christian quest for order made possible the idea of a purely immanent good order (Taylor 2010a: 305306). This immanent, self-sufficient order was seen as composed "of rights-bearing individuals, who are destined (by God or nature) to act for mutual benefit” (Taylor 2010a: 305). Taylor maintains that this new self-understanding was equally important for the rise of modern society as the social changes pointed out by Benedict Anderson, whose work on the construction of nations as "imagined communities" ([1983] 2006) has greatly influenced Taylor: "Modern society also required transformations in the way we figure ourselves as societies" (Taylor

13 On this aspect, see also the contribution by Bender in this volume (286fn4). 
1998: 42). To this I wish to add that not only "the way" but the very fact that "we figure ourselves as societies" is specifically modern - hence the potential of the concept 'society' for discerning the modern imaginary.

Indeed, society is equally as imaginary as nation, whose evolution and spread Anderson has so brilliantly analyzed. The historicity and normativity of 'society' might be more obscure than with 'nation' due to the fundamental role society plays in our background understandings. We can hardly imagine our lives not taking place in society, and tend to project the concept of 'society' back across ages. Yet, rather than imaging their society differently, pre-modern people did not imagine their collectivity as society at all. For what Mary Poovey (2002: 125) has shown for 'the social' is equally true for 'society' as an abstract entity: it "has become thinkable [only] as part of the long history of reification that we call modernity." Phil Withington (2010) traces the origins of 'society' in sixteenth century England, a formative period for modernity at large (and indeed the evolution of 'society' was intrinsically connected with the evolution of 'modern' itself). The normative core of the concept of 'society' was to be a "voluntary and purposeful association" (Withington 2010: 12, 105) of free individuals. This normative core was maintained when the scope of 'society' was widened from individual corporations to society as an all-encompassing social sphere.

Thus the normative core of 'society' mirrors the meta-norm of Taylor's three social imaginaries, which consists of free individuals, voluntarily and purposefully assembling for mutual benefit. Indeed, Taylor once (ASA: 156) defines the social imaginary itself as "the ways we are able to think or imagine the whole of society." In this sense, A Secular Age is the story of the shifting background understandings about society, whose specifically modern understanding, I then add, is expressed by the concept of 'society.' In other words, what Taylor characterizes as specific for modern societies is in fact characteristic of 'society' tout court.

\section{5 'Society' in al-Manar}

As stressed above, one can hardly aim at discerning the modern social imaginary of Muslims at large, but only that of a specific group of people. The latter can, however, be selected so as to be representative of more general trends. This is the case with the group of authors around the journal al-Manar, which I have selected as the corpus of the following analysis for four reasons: Firstly, al-Manar, published in Cairo from 1898 to 1940, witnessed a formative period of modernity and distinguished itself from the vast number of short-lived newspapers and journals by virtue of its duration. Secondly, al-Manar presumably addressed 
the concept of 'society,' since the subtitle of the journal's first issue read, “a journal for the philosophy of religion and the affairs of human society and of civilization" (majalla fī falsafat al-dīn wa-shu'ūn al-ijtimă' wa-l-'umrān). Thirdly, alManar came to be widely acknowledged as the mouthpiece of Islamic modernism. The influence of al-Manar beyond Egypt and to the present day is well documented (see, for example, Azra 2008; Burhanudin 2005; Hamzawy 2004). According to their self-description, the Islamic modernists of al-Manar aimed at harmonizing or combining Islam and (Western) modernity. The perpetuation of this normative claim by secondary literature in seemingly neutral descriptions is not unproblematic, but for present purposes it is useful, as it suggests Islamic modernism as a location where we might find a vision of an Islamic modernity which interweaves aspects of European modernity and secularity with the Islamic discursive tradition. The fourth advantage of al-Manar is of a practical nature: the journal is available in an electronic version, ${ }^{14}$ which allows for a comprehensive term search of its nearly 30,000 pages.

Before getting to this search, let me briefly outline the relevant setting of alManar. Clearly the authors of al-Manar were confronted with secularist claims. Some were of a practical nature, especially in the fields of politics, law, and education, not least because Egypt was occupied by England in 1882; but others were of an ideological nature, since European secularist, nationalist, and socialist ideas were present to and in fact adopted by Arab thinkers. ${ }^{15}$ The Islamic modernists, at least in their writings, did not uphold secularist stances but were part of a secular situation insofar as their voices were among many in an increasingly diverse public sphere. This pluralization of stances is best mirrored by the diversification of newspapers and journals in the last decades of the nineteenth century (Ayalon 2010). Within this arena, al-Manar was clearly the most prominent "Islamic journal," a label by which it was known at the time (alHadi 1905). One recalls here the importance Benedict Anderson ([1983] 2006) attributes to print capitalism for the emergence of modern nations. Newspapers facilitate a sense of belonging and solidarity among people who have never met;

14 The electronic version is available from al-Maktaba al-Shamila: http://shamela.ws/index. php/book/6947 (last accessed September 13, 2013); for information on this website, see Gilet (2010). This version proved reliable, except that it does not include the Qur'an commentary (tafsir), which accounts for more than a fifth of the journal's overall content. I filled this gap by using an electronic version of the tafsir, which was published separately later. This electronic version is available here: http://shamela.ws/index.php/book/12304 (last accessed October 28, 2013). I have crosschecked all passages identified via the electronic versions against the printed versions and quote only the latter. The printed version of the tafsir I used is Rida (1948-1961). 15 For the spread of leftist ideologies in al-Manar's rival journals, see Khuri-Makdisi (2013). 
they not only greatly support the nation as an imagined community, but also as a society.

Now, attempts to discern the specifically modern notion of society in alManar are facilitated by the fact that an Arabic term gained prominence to express this concept: mujtama'. Talal Asad, with his ingenious grasp of epistemological shifts in the development of modernity, has pointed to the significance of the evolution of mujtama'. He has written, in regards to the 1899 court reforms proposed by Muhammad 'Abduh, the greatest modern Muslim reformist and a protagonist of al-Manar, that: "The modern Arabic word for society (mujtama') [was] not yet linguistically available, nor [was] the modern concept to which it now refers" (Asad 2008: 229). However, while a conceptual history of mujtama is still missing, there are hints that the term had already evolved to express the modern European concept of 'society' by the end of the nineteenth century: A series of Arabic encyclopedias, which provide examples for the usage of key terms and list Arabic expressions for European terms, do not list mujtama' in the volume covering the years 1700 to 1890 (Dughaym 2000: 1365). This changes in the volume covering the years 1890 to 1940 , which roughly coincides with the life span of al-Manar. Here, mujtama' is listed as an expression of 'society' and its French pendant société (al-'Ajm 2002: 1219). A telling example is given from a book by Ameen Rihani, a Lebanese emigrant to the United States, who wrote in 1910, “al-Mujtama'! Irfa'ūhu 'alā al-ḥukūma wa-l-ḥukkām [Society! Elevate it over the government and the rulers]” (al-Rihani 1956, 1: 190, taken from al-'Ajm 2002: 944). The normative usage of society in this instance hardly requires elaboration. Ameen Rihani wrote in both English and Arabic, and his particular cultural position "between the 'West' and the 'East"” (Schumann 2008) might partially explain why we find an Arabic expression of 'society' in his works. Indeed, familiarity with European thought greatly facilitated the usage of mujtama', as the following analysis of al-Manar will demonstrate.

The search for mujtama in al-Manar produced a total of 358 instances. Not all of these, however, refer to society as an overall social sphere. Since these other cases are relevant for establishing the semantic range of mujtama' and specifying which authors popularized the modern meaning of mujtama' as 'society,' I will briefly summarize them here: In 19 cases the reference is to an assembly of something other than people, for example stars in a zodiac (al-Tunisi 1921: $218 / 21)^{16}$ or a confluence of water (Rida 1898a: 176/11; 1930: 50/14); eight times a specific club or association is addressed, for example student clubs (Rida 1907: 933/21) or welfare organizations (Sidqi 1905: 778/22); twelve times

16 References to instances of mujtama' in al-Manar are by page/line. 
mujtama' means 'place of assembly' (Rida 1899: 285/2) and 58 times it refers to the assembly itself, either to a gathering or get-together (Rida 1898b: 81/15-16, 82/7,9; 1902: 702/13); in 13 instances it is not clear which of the last two meanings is intended (Rida 1898c: 115/9; 1928: 468/3). Regarding an increase or decrease of the different usages over the lifespan of al-Manar, the only noteworthy trend is a declining usage of mujtama' in the sense of 'gathering.' For the meaning of 'society' no significant diachronic trend can be discerned; ${ }^{17}$ however it is remarkable that 'society' was already the dominant meaning of mujtama' in the first issue of al-Manar. Moreover, as the term was used without any explanation, the authors seem to have assumed the readers' familiarity with its meaning society. This meaning continued to dominate throughout the journal's publication: in 138 cases mujtama' refers to (human) society in general, and in 110 cases a particular society or societies are addressed. I formed a separate category for these last cases, as here the specifically modern meaning becomes most obvious.

A first look at the authors ${ }^{18}$ using mujtama' reveals a most interesting finding: al-Manar's editor, Rashid Rida, who also wrote most of the journal's articles, accounts for 66 percent of the instances in which mujtama' does not mean society; his share of mujtama as society in general is only 27 percent, and it drops to ten percent in cases when a particular society is addressed. Moreover, Rida's usages of mujtama' are of a rather scattered nature, as his 38 references to society in general are spread over 30 articles; and nowhere does Rida offer an explicit definition of mujtama'. The latter holds true for the other authors of al-Manar, too. Although not explicitly defined, the broader outlooks of the authors using mujtama' to mean 'society' suggests that the term mujtama' was embedded in and expressive of a broader social imaginary containing normative implications. One should add that while Rida used al-Manar for disseminating his own Islamic reformist ideas, he allowed for a variety of stances to be expressed in his journal and included articles that had been previously published elsewhere.

The one article (Muhaysin 1928) which most frequently uses mujtama in the sense of society in general - 14 times - was first published in the journal al-Siya$s a$, the mouthpiece of the Liberal Constitutionalist Party (Hizb al-Ahrar al-Dusturiyin). This is also the only article to include mujtama' in its title. There are

17 Though one could interpret the declining usage of mujtama' as 'gathering' as an indicator that mujtama' came to mean 'society' more exclusively.

18 I defined the authorship of an occurrence of mujtama' as follows: The case is clear in an article originally written in Arabic and whose author uses mujtama in his own words. I also attributed the term to the author of an article when he (all authors referred to here were male) used it while paraphrasing someone else. In cases of direct quotes, I assigned the instance to the writer being quoted. 
25 instances in which mujtama' is found in translations of European works. Most remarkable of these are the eleven cases to be found in the translation of l'Émile $d u$ dix-neuvième siècle (The Émile of the Nineteenth Century) by French writer and politician Alphonse Esquiros (1869). Esquiros was imprisoned in France in 1841 due to allegedly anti-religious views, yet the entire translation of his book on education, whose title draws on Rousseau's Émile, was published by alManar. Its translator, 'Abd al-'Aziz Muhammad, also once used mujtama' to mean a particular association, rendering l'Académie des sciences as al-mujtama' al-'ilmī (akadìmiyā) (Muhammad 1901: 778/1-2; Esquiros 1869: 168). While this illustrates the different possible meanings of mujtama', Muhammad seems to have identified mujtama' most closely with the meaning of society as overall social sphere since he chose the Arabic term mukhālața when the French société referred to the company of people one is with (Muhammad 1901b: 741/12; Esquiros 1869: 159). The translation of Esquiros's Émile also accounts for ten of the 110 instances in which mujtama' refers to a particular society or societies in the plural.

Particular societies referred to by the authors and worth mentioning here are "the modern civilized society" (al-mujtama' al-madani al-hadìth), "the Turkish society” (al-mujtama' al-turkī), "the Arab society” (al-mujtama' al-'arabì), "the European society" (al-mujtama' al-ūrūbì), "Western societies" (al-mujtama'āt al-gharbiyya), and "the Islamic society" (al-mujtama' al-islāmī). Again the authorship of these instances is remarkable: The reference to a specifically modern society is most clearly elaborated in an article by the Indian Muslim reformer Amir 'Ali, which was originally written in English and translated for Egypt's leading daily newspaper al-Mu'ayyad, after which it was reprinted in al-Manar ('Ali 1913). The concept of an Arab society first appears in al-Manar in 1919, in a translation of excerpts from the work Psychologie politique by French philosopher and sociologist Gustave Le Bon (Le Bon 1912; 1920). The only author who originally wrote in Arabic and referred to an Arab society or societies is 'Abdallah 'Anan in 1927. He also speaks of "Turkish society," "European society," "Western societies," and "Islamic society." All these instances appear in two articles first published in al-Siyasa. It certainly is no coincidence that 'Anan translated the doctoral thesis of Taha Husayn, which was written under supervision of Émile Durkheim, a founding father of sociology (Husayn 1917; 2006 [1925]). The term société appears on every other page of Husayn's text. Whenever société is used to refer to society as an abstract entity (which mostly is the case), 'Anan translated it as mujtama'. Yet he prefers the Arabic term jamā' $a$, when société refers to a specific group or organization (for example, Husayn 1917: 68-69; 1925: 58 -59). This establishes the distinct meaning mujtama' had acquired in circles 
familiar with European social thought in the first decades of the twentieth century.

With one exception (al-'Azm 1899: 867/24), the authors who regularly wrote for al-Manar refer to only one particular society by name: "the Islamic society." This composite occurs sixteen times in al-Manar, ${ }^{19}$ with two instances originated by Rida. In one of those (Rida 1900: 757/9), Rida picks up a central topic of his overall writing when he portrays nationalism (al-jāmi a al-wațaniyya) as a threat to the body of the Islamic society (jism al-mujtama' al-islāmī) and to the religious bond (al-rābița al-dìniyya). The one regular author who comes closest to defining features of an Islamic society is Hasan al-Banna. In 1928, al-Banna (1906-1949) founded the Muslim Brotherhood, the most influential movement of political Islam to date, under whose auspices the last volume of al-Manar appeared after Rida's death. In this volume from 1940, al-Banna tackles the relation between men and women in society. He stresses that Islam regards the mingling of men and women outside marriage as dangerous, since: "the Islamic society is a segregated society, not a joint society [al-mujtama' al-islāmī mujtama' fardī/infirāà̄ lā mujtama zawjī/mushtarak]” (al-Banna 1940:767/7-8, 768/7-8). That we come closest to a definition of mujtama' as society in the last volume of al-Manar suggests that the term was increasingly a focal point for debates about social order. However, immediately following this quote, al-Banna uses mujtama' to mean gatherings or places of assembly, indicating that the term continued to hold multiple layers of meaning.

While these other meanings of mujtama' should not be overlooked, the more important finding of this analysis remains that society was already the dominant meaning of mujtama' in the first issue of al-Manar in 1898. Remember that according to Talal Asad, who ingenuously pointed to the epistemological shift expressed by the evolution of mujtama', the term did not acquire the meaning of society until later. ${ }^{20}$ It is certainly true that the authors of al-Manar did not yet debate and argue over mujtama' as a central concept. Nevertheless the authorship of the term as 'society' clearly indicates the channels through which this meaning gained prominence in Arabic. This suggests that the term was associated with implicit normative connotations, most likely those associated with 'society' in European languages, namely, a reified entity, autonomous from the state, in which free individuals interact for mutual benefit.

19 There are two other occurrences of al-mujtama' al-islāmī, however these refer to an Islamic association or assembly.

20 Relying on dictionaries, Asad (2008: 198fn24) mentions the 1930s as the period when mujtama' gained prominence. 
That al-Manar's editor and its most productive author, Rashid Rida, barely used mujtama' to mean 'society' could be read as his non-participation in the modern social imaginary expressed by the term. However, other facts speak against this reading: The turn to, and even primacy of, societal affairs has long been recognized as a central trait of Rida's reform efforts (Adams 1933: 187; Arslan 1933: 636/17; Haddad 2008). And Rida does stand out in his mostly positive references to sociology in al-Manar, accounting for 99 of the 132 occurrences of 'ilm al-ijtimā', the Arabic term for 'sociology.' I would therefore like to hypothesize that Rida expressed the modern social imaginary in terms other than mujtama', most interestingly, umma.

We do know (Ayalon 1987: 26-28; Rebhan 1986: 24-35) that umma in the nineteenth century acquired the meaning of 'nation,' alongside its established meaning of 'community of believers;' yet before mujtama' was firmly established, umma might also have served to express the modern concept of society. Clearly, umma was a very flexible term at the turn of the twentieth century: Ahmad Fathi Zaghlul, in his translation of Demolins's A quoi tient la supériorité des Anglo-Saxons from 1899, indiscriminately uses umma for the original terms nation, communauté, société, and even race (Demolins 1897; 1899). In al-Manar's first volume, Rida states that mujtama' and "civilized umma" (al-umma al-mutamaddina) are synonyms for the meaning of $a$ l-sha' $b$ (the people) (Rida $1898 \mathrm{~d}$ : 220/17). And in the same year, Rida twice writes that "the umma comes into existence (tatakawwan) by rallying around the beneficial (al-ijtimā' 'alā l-intifā') and uniting to obtain what is desired (al-ittiḥād 'alā l-murād)" (Rida 1898e: 328/17-18). For Rida, umma might have provided an alternative discursive means for speaking about society. In other words, Rida did participate in the modern social imaginary, yet articulated it in an Islamic discourse. From within this discourse, of which umma, contrary to mujtama', traditionally forms a part, Rida advocated an Islamic modernity that related an increasingly autonomous worldly sphere to a transcendental reality.

The foregoing exploration had two aims: Firstly, to show the potential of Taylor's modern social imaginaries to illuminate the fundamental commonalities between seemingly adverse positions. Secondly, to illustrate the potential of concept analysis for a preliminary grasp on these imaginaries. Of course, the more detailed contours of the modern social imaginary held by Rida and other Islamic modernists require a more specific analysis of their writings. An example of such an analysis is Richard van Leeuwen's (2008) analysis of Rida's theory of miracles. Translated into Taylor's framework, van Leeuwen shows how Rida aimed at clearing society's immanent frame of magic and transcendental interference, relegating religion to an autonomous sphere of its own. Further establishing the participation of Islamic modernists in our common secular age goes along with 
another question, namely whether the Islamic modernists, like Taylor, resorted to story-telling as a mode of advancing their particular vision of modernity.

\section{Epilogue: Fundamentalism as a mode of appropriating modernity}

Why does Charles Taylor tell a story? On the normative side he wants to show the Christian roots of our secular age, thereby rendering plausible the existence of a transcendent reality and strengthening the option of belief in a Christian God today. In regards to the underlying epistemology, Taylor's reason for resorting to story-telling is the assumption that “we (modern Westerners) can't help understanding ourselves in these terms [i.e. via master narratives]. I'm not claiming this for all human beings at all times" (Taylor 2010a: 300). Indeed, the Islamic modernists at the turn of the twentieth century did not narrate a continuous, autochthonic genealogy of modernity. Yet this was due less to a different epistemology than to colonial power structures. After all, why can Taylor tell the story he is telling? Why does his exclusivist Western story work, despite its lack of attention to the historical role of the non-West in shaping our present self-understandings? It only does work because of the West's political, economical, and cultural hegemony and seeming self-sufficiency.

Try to imagine being a modernist Muslim intellectual at the beginning of the twentieth century, like Rashid Rida, who wants to tell an exclusivist genealogy of an autochthonic Islamic modernity. He can't. That is, his story won't be very plausible or convincing, since Europe's contribution to the present state of affairs is too obvious to ignore. The potential alternative, telling a common story - which would probably best mirror historical reality - was inhibited by colonialists' exclusivist claims to modernity. Colonialists mainly upheld what Taylor terms "subtraction stories," the logic being that in Christendom reason has emancipated itself from the bonds of religion and this must happen in Islam, too. In Egypt, it was a minority of secularist thinkers who wholeheartedly embraced the Europeans' path and story of secularity as presented to them. At the other end of the spectrum, traditionalists did not pursue participating in modernity in the first place. The Islamic modernists, meanwhile, wanted to participate in modernity, but wanted their own Islamic version instead of following the allegedly areligious European model. In so doing they were buying into European subtraction stories when they maintained that in Christendom, the liberation from religious bonds was necessary to achieve modernity. They then ar- 
gued that this was not true for Islam since its fundamentals, mainly the Qur'an, already contained all the positive aspects of modernity.

Rashid Rida and Muhammad 'Abduh, the protagonists of al-Manar, played a key role in the modern process of reification, which enforces focusing on the fundamentals or the alleged core of a religion (Tayob 2009; Jung 2011). In their search for appropriate answers to contemporary questions, they rejected the bulk of tradition, that is, of historically contingent elaborations, and instead focused on an alleged universal essence of Islam, which they saw embodied mainly in the Qur'an. In the Qur'an they distinguished between verses to be taken literally, especially those concerning matters of worship ('ibādāt), and verses in which God illustrated his intentions by clothing them in historically contingent examples. The latter concerns the vast realm of social affairs (mu'āmalāt), in which human reason was to elaborate answers appropriate for the present in light of God's underlying intentions. For this, the Sunna, the deeds and sayings of the prophet Muhammad, mainly served to elucidate the Qur'an. A third point of reference next to the Qur'an and Sunna were the pious forefathers of Islam (alsalaf al-șâlih), who allegedly alone truly enacted the word of God and lived the spirit of Islam. Due to their reference to the salaf, the Islamic modernists 'Abduh and Rida are also known as protagonists of the salafiyya (Lauzière 2010: 370). And in turn, this focus on the fundamentals of Islam earned some Islamic modernists, especially Rida, the label of 'fundamentalist.'

What might sound contradictory at first actually brings to light the Islamic modernists' mode of legitimizing and critiquing modernity: all the positive elements of modernity were already present in the fundamentals of Islam; the negative aspects of Western modernity are however absent. In other words, the Islamic fundamentals embody modernity in perfection. The envisioned modernity is most profoundly characterized by harmonizing religion and reason, spiritually guided ethics and material progress. Whereas in Christendom, reason had to free itself from religion, in Islam reason had always been free within a religious framework. Whereas Christianity did indeed necessitate secularization, Islam neither allows for nor requires secularization, as it has always been secular. 'Abduh (1313 h [1905/1906]), in a book first serialized in al-Manar, offers an elaborated version of this oft-recurring argument - although he, unlike contemporary Muslim reformers (Ramadan 1998: 59-61, 76-81, 114-115; 2001: 89-90, 261, 332-333), does not yet use the term 'secular' or its Arabic equivalent, 'almānì. Now, this argument, which buys into the subtraction stories criticized by Taylor, is of course ahistorical and apologetic; yet it is also a way of appropriating modernity. Equally important, the Islamic modernists' use of Islamic points of reference and an Islamic discourse to address both religious and secular domains makes it harder to see the factual secularity of their thinking. Taylor (ASA: 
736) refers to a similar problem regarding Christian thinkers turning to worldly affairs: "It became hard for many to answer the question, what is Christian faith about? The salvation of humankind, or the progress wrought by capitalism, technology, democracy?"

The fact that the Islamic modernists appropriated modernity via the Islamic fundamentals and thereby negated the supposed need for secularization - that is, for history - might support Taylor's consideration that story-telling is not a culturally universal mode. However, while the modernists were negating the need for one history (secularization) and one story (subtraction), they painted at least the contours of another story, which to pick up Taylor's term (ASA: 774), might be called an "Intellectual Deviation" story. The modernists needed an explanation for why, if the Islamic fundamentals had always contained modernity in perfection, Muslims were now lagging behind Europeans in so many fields. The answer was that Muslims had been betraying the Islamic message and teachings: even directly after the pious forefathers, political strife corrupted the Islamic community; and intellectual life came to a standstill in the thirteenth century, with most scholars blindly following tradition. Colonialism then arguably served as a wake-up call to return to the core teachings of Islam. While even in its longer version this narrative of deviation and its envisioned remedy does not match the complexity of Taylor's Reform Master Narrative, it does suggest that the Islamic modernists also resorted to (hi)story-telling to make sense of themselves and their present state of affairs.

Taylor and the Islamic modernists offer different narratives; they also differ on the aim of such narration, on the state of modernity itself, and on what an alternative modernity might look like. Nonetheless, there are remarkable commonalities between the two. Compare Taylor's intention to show the religious roots and essence of the present secular age with how Aziz al-Azmeh (1996: 106) summarized the basic goals of Islamic Reformism, of which modernism forms part: "Islamic Reformism was founded on the postulation of a possible equivalence between the reality of a secular age and normative religion: theorizing that, given its innate nature, normative religion preceded the reality of today, and consequently should reclaim today as its very own." If we hypothetically picture Rashid Rida walking into a book store with Taylor's story and a subtraction story on display, it seems rather clear which of the two he would have spent his money on, and which would have resonated more with his own understanding of modernity - that story may thus serve as a heuristic tool to better grasp this understanding today. 


\section{Bibliography}

Abbey, Ruth. 2010. "A Secular Age: The Missing Question Mark," in The Taylor Effect. Responding to a Secular Age, ed. Ian Leask, Eoin Cassidy, Alan Kearns, Fainche Ryan, and Mary Shanahan, 8-25. Newcastle upon Tyne: Cambridge Scholars Publishing.

'Abduh, Muhammad. 1323 h [1905/1906]. al-Islam wa-l-Nasraniyya ma'a al-'Ilm wa-l-Madaniyya. Cairo: Matba'at al-Manar.

Adams, Charles. 1933. Islam and Modernism in Egypt. A Study of the Reform Movement Inaugurated by Muhammad 'Abduh. London: Oxford University Press.

al-'Ajm, Rafiq, ed., 2002. Mawsu'at Mustalahat al-Fikr al-'Arabi wa-l-Islami al-Hadith wa-l-Mu'asir, al-juz' al-thānī [vol. 2]: 1890-1940. Beirut: Maktabat Lubnan Nashirun.

'Ali, Amir. 1913. "al-Mar'a qabl al-Islam wa-ba'duhu." al-Manar 16: 933-941.

Anderson, Benedict. [1983] 2006. Imagined Communities. Reflections on the Origin and Spread of Nationalism, revised edition. London/New York: Verso.

Appleby, Scott R. 2011. "Rethinking Fundamentalism in a Secular Age," in Rethinking Secularism, ed. Craig Calhoun, Mark Juergensmeyer, and Jonathan VanAntwerpen, 225 - 247. Oxford: Oxford University Press.

Arslan, Shakib. 1933. "Kalimatan fi al-Shaykh Muhammad 'Abduh wa-l-Sayyid Rashid Rida." al-Manar 33: 635-638.

Asad, Talal. 2008. Formations of the Secular: Christianity, Islam, Modernity. Stanford: Stanford University Press.

Ayalon, Ami. 1987. Language and Change in the Arab Middle East: The Evolution of Modern Political Discourse. New York: Oxford University Press.

Ayalon, Ami. 2010. "The Press and Publishing," in The New Cambridge History of Islam, vol. 6: Muslims and Modernity; Culture and Society since 1800, ed. Robert W. Hefner, 572-596. Cambridge: Cambridge University Press.

[al-'Azm, Rafīq.] 1899. "Man al-Mas'ul, al-Hukuma am al-Sha'b.” al-Manar 1: 866-872. al-Azmeh, Aziz. 1996. Islams and Modernities. London/New York: Verso.

Azra, Azyumardi. 2008. "The Transmission of al-Manār's Reformism to the Malay-Indonesian World: the Case of al-Imām and al-Munīr," in Intellectuals in the Modern Islamic World. Transmission, Transformation, Communication ed. Stéphane A. Dudoignon, Komatsu Hisao, and Kosugi Yasushi, 143-158. London/New York: Routledge.

al-Banna, Hasan. 1940. "al-Mar'a al-Muslima (2)." al-Manar 35: 765-773.

Barre, Elizabeth A. 2012. "Muslim Imaginaries and Imaginary Muslims. Placing Islam in Conversation with A Secular Age." Journal of Religious Ethics 40 no. 1: 138-148.

Bilgrami, Akeel, ed., forthcoming. Secularism Outside of Latin Christendom: Essays in Response to Charles Taylor. New York: Columbia University Press.

Burhanudin, Tajat. 2005. "Aspiring for Islamic Reform: Southeast Asian Requests for Fatwās in al-Manār." Islamic Law and Society 12 no. 1: 9-26.

Connolly, William E. 2010. "Belief, Spirituality, and Time," in Varieties of Secularism in a Secular Age, ed. Michael Warner, Jonathan VanAntwerpen, and Craig Calhoun, 126-144. Cambridge, Mass: Harvard University Press.

Demolins, Edmond. 1897. A quoi tient la supériorité des Anglo-Saxons. Paris: Firmin-Didot. Demolins, Edmond. 1899. Sirr Taqaddum al-Injliz, tarjamat [transl.] Ahmad Fathi Zaghlul. Cairo: Matba'at al-Ma'arif. 
Dughaym, Samih, ed., 2000. Mawsu'at Mustalahat al-Fikr al-'Arabi wa-l-Islami al-Hadith wa-l-Mu'asir, al-juz' al-awwal [vol. 1]: 1700-1890. Beirut: Maktabat Lubnan Nashirun.

Esquiros, Alphonse. 1869. L'Emile du dix-neuvième siècle. Paris: Librairie Internationale.

Gilet, Julien. 2010. “al-Maktaba al-Shamela.” Aldébaran, Collections numériques, http://alde baran.revues.orf/6597 (last accessed 30 September 2013).

Göle, Nilüfer. 2010. "The Civilizational, Spatial, and Sexual Powers of the Secular." in Varieties of Secularism in a Secular Age, ed. Michael Warner, Jonathan VanAntwerpen, and Craig Calhoun, 243-264. Cambridge, Mass: Harvard University Press.

Gordon, Peter E. 2008. "The Place of the Sacred in the Absence of God: Charles Taylor's 'A Secular Age'." Journal of the History of Ideas 69 no. 4: 647-673.

Habermas, Jürgen, and Charles Taylor. 2011. "Dialogue," in Judith Butler, Jürgen Habermas, Charles Taylor, and Cornel West, The Power of Religion in the Public Sphere, edited and introduced by Eduardo Mendieta and Jonathan VanAntwerpen; afterword by Craig Calhoun, 60-69. New York: Columbia University Press.

Haddad, Mahmoud. 2008. "The Manarists and Modernism. An Attempt to Fuse Society and Religion," in Intellectuals in the Modern Islamic World. Transmission, Transformation, Communication, ed. Stéphane A. Dudoignon, Komatsu Hisao, and Kosugi Yasushi, 55-73. London: Routledge.

al-Hadi, Shaykh bin Ahmad. 1905. "al-Manar al-Islami wa-l-Liwa' al-Watani." al-Manar 8: $478-479$.

Hamzawy, Amr. 2004. "Exploring Theoretical and Programmatic Changes in Contemporary Islamist Discourse: The Journal al-Manar al-Jadid," in Transnational Political Islam. Religion, Ideology and Power ed. Azza Karam, 120-146. London/Sterling, Virginia: Pluto Press.

Hauerwas, Stanley, and Romand Coles, “'Long Live the Weeds and the Wilderness Yet': Reflections on A Secular Age." Modern Theology 26 no. 3: 349-362.

Husayn, Taha. 1917. La philosophie sociale d'Ibn-Khaldoun. Paris: A. Pedone.

Husayn, Taha. 1925. Falsafat Ibn Khaldun al-Ijtima'iyya: Tahlil wa-Naqd, trans. Muhammad 'Abd Allah 'Anan. Cairo: Matba'at al-I'timad.

Jung, Dietrich. 2011. Orientalists, Islamists and the Global Public Sphere: a Genealogy of the Modern Essentialist Image of Islam. Sheffield/Oakville: Equinox.

Khuri-Makdisi, Ilham. 2013. "Inscribing Socialism into the Nahḍa: al-Muqtațaf, al-Hiläl, and the Construction of a Leftist Reformist Worldview, 1880-1914," in The Making of the Arab Intellectual (1880-1960): Empire, Public Sphere and the Colonial Coordinates of Selfhood, ed. Dyala Hamzah. 63-89. London: Routledge.

Krämer, Gudrun. 2013. "Modern but not Secular: Religion, Identity and the ordre public in the Arab Middle East." International Sociology 28 no. 6: 629-644.

Künkler, Mirjam, John Madeley, and Shylashri Shankar, eds., forthcoming. A Secular Age Beyond the West.

Lauzière, Henry. 2010. "The Construction of Salafiyya: Reconsidering Salafism from the Perspective of Conceptual History." International Journal of Middle East Studies 42: $369-389$.

Le Bon, Gustave. 1912. La Psychologie politique et la Défense sociale. Paris: Ernest Flammarion.

Le Bon, Gustave. 1920. "Namudhaj min Kitab al-Falsafa al-Siyasiyya," tarjamat [trans.] 'Abd al-Basit Efendi Fath Allah al-Bayruni. al-Manar 21: 345-53. 
Loeffler, Reinhard. 1988. Islam in Practice: Religious Beliefs in a Persian Village. New York: State University of New York Press.

van Leeuwen, Richard. 2008. "Islamic Reformism and the Secular: Rashid Ridâ's Theory on Miracles," in Religion and Its Other. Secular and Sacral Concepts and Practices in Interaction, ed. Heike Bock, Jörg Feuchter, and Michi Knecht, 64-78. Frankfurt am Main: Campus.

Madsen, Richard. 2011. "Secularism, Religious Change, and Social Conflict in Asia," in Rethinking Secularism, ed. Craig Calhoun, Mark Juergensmeyer, and Jonathan VanAntwerpen, 248-269. Oxford: Oxford University Press.

Mahmood, Saba. 2010. “Can Secularism Be Other-wise?" in Varieties of Secularism in a Secular Age ed. Michael Warner, Jonathan VanAntwerpen, and Craig Calhoun, 282-299. Cambridge, Mass: Harvard University Press.

al-Manar. Cairo: Matba'at al-Manar, vols. 1 (1315 h [1898]) - 35 (1358 h [1940]).

Milbank, John. 1991. Theology and Social Theory: Beyond Secular Reason. Cambridge: Blackwell.

Miller, James. 2008. "What Secular Age?." International Journal of Politics, Culture, and Society 21 no. 1: 5-10.

Muhammad, 'Abd al-'Aziz. 1901a. "Amil al-Qarn al-Tasi' 'Ashar.” al-Manar 3: 771-788.

Muhammad, 'Abd al-'Aziz. 1901b. "Amil al-Qarn al-Tasi' 'Ashar.” al-Manar 3: 737-743.

Muhaysin, Hamid Mahmud. 1928. "al-'Uquba fi al-Islam laysat Taqriran li-Nazariyyat al-Intiqam: al-Mujtama' la budda li-Nizamihi min Tashri' al-'Uqubat." al-Manar 29: $299-308$.

Ophir, Adi. 2011. "Concept.” Political Concepts - A Critical Lexicon 1, http://www.political concepts.org/2011/concept (last accessed February 12, 2014).

Poovey, Mary. 2002. "The Liberal Civil Subject and the Social in Eighteenth-Century British Moral Philosophy." Public Culture 14 no. 1: 125-145.

Ramadan, Tariq. 1998. Les musulmans dans la laïcité: responsabilités et droits des musulmans dans les sociétés occidentales. Lyon: Tawhid.

Ramadan, Tariq. 2001. Islam, the West and the Challenges of Modernity, trans. Saïd Amghar. Leicester: The Islamic Foundation.

Rebhan, Helga. 1986. Geschichte und Funktion einiger politischer Termini im Arabischen des 19. Jahrhunderts (1798-1882). Wiesbaden: Otto Harrassowitz.

Rida, Rashid. 1898a. "al-Shi'r wa-l-Shu'ara'." al-Manar 1: 170-177.

Rida, Rashid. 1898b. "al-Mawalid aw al-Ma'arid.” al-Manar 1: 79-87.

Rida, Rashid. 1898c. "Kayfa al-Sabil?!.” al-Manar 1: 112-119.

Rida, Rashid. 1898d. "Sayhat Haqq." al-Manar 1: 217-225.

Rida, Rashid. 1898e. "Mashru' Sikkat Hadid bayna Bur Sa'id wa-l-Basra." al-Manar 1: $318-331$.

Rida, Rashid. 1889. "Athar 'Ilmiyya Adabiyya: al-Kitaban al-Jalilan.” al-Manar 2: 282-286.

Rida, Rashid. 1900. "al-Hayra wa-l-Ghumma wa-Manashi'uhuma fi al-Umma." al-Manar 2: $753-758$.

Rida, Rashid. 1902. "Bab al-As'ila wa-l-Ajwiba." al-Manar 5: 699-703.

Rida, Rashid. 1907. “Khutbat al-Duktur Diya' al-Din Ahmad,” al-Manar 9: 933-939.

Rida, Rashid. 1928. “Haqa'iq fi 'Adawat Malahidat al-Turk li-l-Islam.” al-Manar 29: 464-474.

Rida, Rashid. 1930. “Fatawa al-Manar,” al-Manar 31: 46-58. 
Rida, Rashid. 1948-1961. Tafsir al-Qur'an al-Hakim, al-Mushtahar bi-Tafsir al-Manar, 12 vols. Cairo: Maktabat al-Qahira.

al-Rihani, Amin. [1910] 1956. al-Rihaniyyat, 2 vols. Beirut: Dar al-Rihani li-l-Tiba'a wa-l-Nashr. Schielke, Samuli. 2012. "Being a Nonbeliever in a Time of Islamic Revival: Trajectories of Doubt and Certainty in Contemporary Egypt." International Journal of Middle East Studies 44: 301-320.

Schumann, Christoph. 2008. "Within or Without? Ameen Rihani and the Transcultural Space between the 'West' and the 'East'," in Liberal Thought in the Eastern Mediterranean: Late 19th Century until the 1960s, ed. Christoph Schumann, 239-266. Leiden/Boston: Brill.

Schweiker, William. 2009. "Our Religious Situation: Charles Taylor's A Secular Age." American Journal of Theology \& Philosophy 30 no. 3: 323-329.

Sheehan, Jonathan. 2010. "When Was Disenchantment? History and the Secular Age," in Varieties of Secularism in a Secular Age, ed. Michael Warner, Jonathan VanAntwerpen, and Craig Calhoun, 217-242. Cambridge, Mass: Harvard University Press.

[Sidqi, Muhammad Tawfiq.] 1905. "al-Din fi Nazr al-'Aql al-Sahih (6)." al-Manar 8: 771-783. Strauss, Claudia. 2006. "The Imaginary." Anthropological Theory 6 no. 3: 322-344.

Tayob, Abdulkader. 2009. Religion in Modern Islamic Discourse. London: Hurst.

Taylor, Charles. 1998. "Modes of Secularism," in Secularism and Its Critics, ed. Rajeev Bhargava, 31-53. New Delhi: Oxford University Press.

Taylor, Charles. 2004. Modern Social Imaginaries. Durham/London: Duke University Press. Taylor, Charles. 2010a. "Afterword: Apologia pro Libro suo," in Varieties of Secularism in a Secular Age, ed. Michael Warner, Jonathan VanAntwerpen, and Craig Calhoun, 300-321. Cambridge, Mass: Harvard University Press.

Taylor, Charles. 2010b. "Challenging Issues about the Secular Age." Modern Theology 26 no. 3: $404-416$.

Taylor, Charles. 2010c: “Charles Taylor replies [to Tester (2010)].” New Blackfriars 91 no. 1036: 677-679.

Taylor, Charles. 2011a. "Western Secularity," in Rethinking Secularism, ed. Craig Calhoun, Mark Juergensmeyer, and Jonathan VanAntwerpen, 31-53. Oxford: Oxford University Press.

Taylor, Charles. 2011b. "Response." The Australian Journal of Anthropology 22: 125-133.

Tester, Keith. 2010. "Multiculturalism, Catholicism and Us." New Blackfriars 91 no. 1036: 665-676.

[al-Tunisi, Muhammad al-Khidr]. 1921. "al-Khayal fi l-Shi'r al-'Arabi (2)." al-Manar 22: $218-227$.

Withington, Phil. 2010. Society in Early Modern England. The Vernacular Origins of Some Powerful Ideas. Cambridge/Malden: Polity. 
Brought to you by | Universitätsbibliothek Bern

Authenticated | florian.zemmin@islam.unibe.ch author's copy Download Date | 4/1/16 9:23 AM 